\title{
Integrating African Pentecostalism into the theological education of South African Universities: An urgent task
}

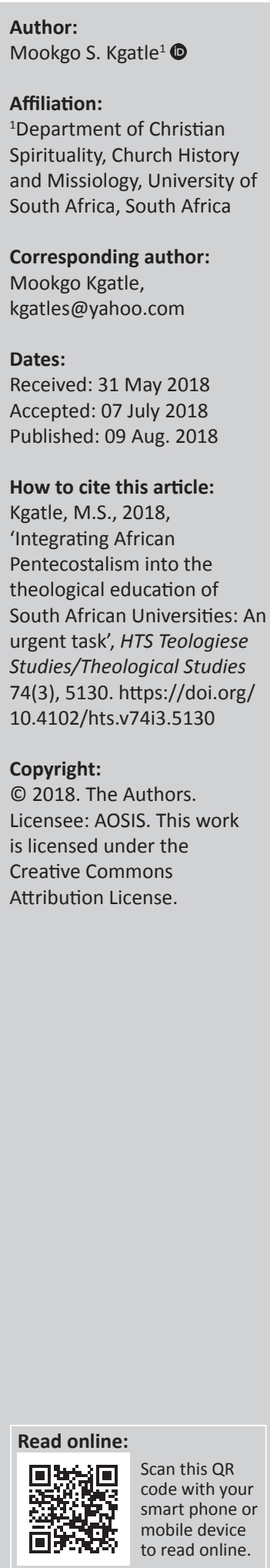

African Pentecostalism continues to be a growing part of Christianity both in Africa and the rest of the world. Pentecostal churches in Africa are on the rise at a very high rate. However, theological education in South African universities does not reflect this reality, but continues to be of a western orientation. Therefore, there is an urgent need and demand for a theological education that will be relevant to Africa. It is an urgent need for African Pentecostalism to be integrated into the theological education of South African universities. This can be achieved by integrating African Pentecostalism into the curriculum, by decolonising Pentecostal research and by the emergence of critical African scholars that can address cutting-edge issues in a South African context. Thus, theological education in South African universities shall be a contextual and relevant one.

\section{Introduction}

Pentecostalism is defined broadly to include those Christians who consider themselves Pentecostal or Charismatic, embracing the works of the Holy Spirit in the first-century church as described in Acts and elsewhere in the New Testament as relevant and normative for contemporary Christians (Hittenberger 2001:218). Pentecostalism continues to be a growing part of Christianity in the world. A report on the Size and Distribution of the World's Christian Population estimates a membership of 279 million (see Pewforum 2011:1). The geographical breakdown of this membership reveals that the overwhelming part of this Christianity belongs either to the 'Indigenous Non-White' or to the Third World Pentecostal churches (Hollenweger 1986:403).

Pentecostalism in Southern Africa is mainly taught and researched in Bible schools and seminaries. In the beginning, the Pentecostal approach to theological education, according to Kay (2004:229), concerned the education offered to ministers and leaders of churches. Subsequently, it expanded to other forms of training. The seminary where I was trained as a pastor is dedicated to the Pentecostal approach to teaching, learning and research. However, Pentecostalism should make its footing in the mainstream universities in southern Africa. This is simply because the quality of teaching, learning and research at Bible schools and seminaries is of a lower quality in content in comparison to mainstream universities, as many of them are not accredited by the Department of Higher Education and Training. There is also a challenge of funding in Bible schools and seminaries which could compromise quality.

Balcomb (2015:8) says that it is surprising that African Pentecostalism is most neglected and sidelined in the modern academy, given the numerical growth of this movement that continues to outstrip all other sectors of Christianity. Balcomb points out that their accommodation in the academy represents a major challenge not only because they are increasingly demanding theological education at the highest level, but also because the oral nature of the theologies that are emerging from the grassroots of their movements still need to be documented and put into dialogue with other theologies (Balcomb 2015:8). Balcomb continues to say that a great deal of research has been conducted, especially in the social sciences, but more needs to be done theologically and find its way into mainstream theology in the University (Balcomb 2015:9).

This article attempts to demonstrate the ways in which challenges of incorporating African Pentecostalism in the universities, as raised by Balcomb, can be addressed as a matter of urgency. African Pentecostalism in this article is described based on experience and theology. However, African Pentecostalism is not prescribed as a dominating approach but rather as part of an 
integrated theological education. There is therefore a need for integration in the curriculum, decolonisation of Pentecostal research and emergence of critical African scholars that can address cutting-edge issues in a South African context in order to move towards a Pentecostal approach in the theological education of South African universities.

\section{An overview of theological education in South African universities}

Theology in South Africa developed in a close relationship with theology in European countries, such as Scotland, the Netherlands and, to a lesser extent, Germany. Local developments closely followed developments in Europe, with an import of ideas through postgraduate studies of South African students at these universities and regular research visits to and from European scholars. It is only in the last two decades that theologians in South Africa slowly started to develop an indigenous (South) African theology (see Dreyer 2017:4). Indeed, the exportation of western education continues the imperialism of the past and perpetuates the legacy of colonialism. According to Ramantswana (2016:408), this happens 'when African scholars choose to follow Western or European hermeneutical frameworks in Africa, such hermeneutics is not African; rather, it is Western or European hermeneutics duplicated in Africa'. For this situation, Ramantswana proposes that African scholars need to start paying attention to African epistemological and philosophical framework(s) (2016:408). Thus, African scholars should develop their own 'theological paradigms to challenge and transform theological education throughout the world' (Kay 2004:233).

Theological education in South African universities is diverse as it comprises different denominations and approaches to a level that it is not easy to single out one denomination or approach to be the only one in theological education. Venter (2016:2) adds that, historically, the study of theology and theological education has been institutionalised in diverse forms, for example, in ecclesiastical seminaries, or even at church-oriented universities, and the question where theology should be primarily located is a perennial one. Some churches prefer private institutions; Reformed churches in South Africa have consistently realised the importance of the public university.

\section{Naidoo (2016) puts it this way:}

South Africa, theological education, like everything else, has been racialised and informed by different ideologies that either supported or opposed apartheid. Theological education in South Africa reflects the deep divides of the context within which it is situated - South Africa itself is politically, economically and culturally a contested space and theological education is equally complex and heterogeneous. This complexity within theological praxis calls for an approach that takes on a diversity of perspectives of cultural, public and Christian life, with Africanisation representing one of these 'other' perspectives. (p. 3)

In this article, African Pentecostalism is prescribed as one of the approaches that will integrate a theological education in
South African universities. It is prescribed as an approach that will indigenise theological education and decolonise the western approach to theological education. Decolonisation according to Ramantswana (2017) is:

the deliberate move not to abandon our own heritage is to reject the Western cultural imposition that places Western culture as the universal to which the rest have to adhere. (p. 5)

Heleta (2016) cautions that decolonisation should neither be:

an advocacy to be anti-west, nor discouragement to learn from the west and the rest of the world. Rather, a call to make higher education relevant to the material, historical and social realities of the communities in which universities operate. (p. 4)

Thus, decolonisation is more of a pro-black and pro-African project than an anti-west project. In other words, it is not about hating the west but loving Africa the more. It is a project of both embracing and nourishing African values and culture.

It is therefore important in order to experience decolonisation in full to connect it to Africanisation. Africanisation according to Letsekha (2013:5) is often described as a renewed focus on Africa and entails salvaging what has been stripped from the continent. Mashau (2003:126) argues that 'Western missionaries marginalised virtually everything that had to do with the traditional African worldview. They have succeeded in convincing Africans to dress, talk, walk and eat like them'. Letsekha continues to say that when applied to higher education, Africanisation can be viewed as a call to adapt curricula and syllabuses to ensure that teaching and learning are adapted to African realities and conditions. It is a learning process and a way of life for Africans. It involves incorporating, adapting and integrating other cultures into and through African visions to provide the dynamism, evolution and flexibility so essential in the global village. Africanisation is the process of defining or interpreting African identity and culture. It is formed by the experiences of the African Diaspora and has endured and matured over time from the narrow nationalistic intolerance to an accommodating, realistic and global form (2013:5).

Integration of African Pentecostalism into the curriculum of South African universities will assist in making theology to be relevant to South Africans in their context, in the sense that it will decolonise higher education on one hand and Africanise higher education on the other. Of course, one does not attempt to make African Pentecostalism to be the only answer to the challenges facing theological education in South African universities but perceive it as one of the solutions to such problems. There are challenges facing theological education such as the ones highlighted by Hadebe when he quoted Wahl, who lists four current challenges as 'access; the lack of resources; sociopolitical and socialeconomic illness; and an Africanised scholarship and curricula' (Hadebe 2017:3; cf. Wahl 2013:269). These are more general challenges facing the whole system of higher education in South Africa. However, Hadebe continues to 
highlight challenges that are peculiar to theological education by quoting Amanze who addresses:

the decline in numbers and research output of theological faculties in universities across Africa as caused by government's quest for social and economic development driven by science, not religion; the abstract nature of theology inherited from western paradigms which fails to address contemporary issues affecting the life of Africans in concrete terms. (Hadebe 2017:3; cf. Amanze 2012:197)

African Pentecostalism is one of the approaches that can address challenges such as the ones highlighted above. However, African Pentecostalism should not be a homogenous approach but part of other approaches. Otherwise, it might run the risk of correcting a wrong with another wrong of monopolising scholarship. A non-conclusive and nonexhaustive list of theological approaches includes, among others, Apologetics/polemics, Biblical hermeneutics, Biblical studies, Biblical theology, Constructive theology, Dogmatic theology, Ecumenical theology, Exegesis, Historical theology, Homiletics, Moral theology, Natural theology, Patristics or patrology, Philosophical theology, Practical theology, Spiritual theology, Systematic theology, Theological aesthetics, Black theology, Contextual theology and Theological hermeneutics. These approaches are practiced in many South African universities and many remain westernised or of western epistemology. African Pentecostalism should be integrated into these and other approaches to make theology relevant to the current developments in Africa.

\section{African Pentecostalism as an approach to theological education}

Buitendag and Simut (2017:3) in their article 'teaching theology at African public universities as decolonisation through education and contextualisation' demonstrate that if there is a future for theology in the world, then there is most certainly a place for theology in the university, but Buitendag and Simut highlight the fact that when theology is performed in an academic context, we are automatically faced with the question of method, namely, how should we do theology? (2017:3). This article deals with such a question of methodology. It sees African Pentecostalism as one of the approaches that can be used to teach theology at a public university.

It is therefore important to describe this approach so that we know what it entails. In the words of Alvarez (2000:281), first, Pentecostalism in general is being passionate for God. It pursues intimacy with the Lord Jesus Christ in the fellowship of the Holy Spirit. Yong (2007:248) adds that because Pentecostalism takes the Spirit's outpouring on all flesh seriously, there is a sense in which it is correct to see Pentecostal theology as a theology of experience. Secondly, it aims towards the fullness of the Holy Spirit in the life of the students. It seeks for a radical dependency on the Holy Spirit both inwardly and outwardly. Thirdly, it is rooted in biblical doctrine. It develops a world view and lifestyle of holiness, consistent with the teachings of the Scriptures. Fourthly, it also aims towards efficacious service and academics. This is reflected in men and women of integrity in all areas of responsibility and service. Fifthly, Pentecostal approach is also dynamic, critical and creative. However, African Pentecostalism according to Kalu (2008:9) is rooted in the indigenous and contemporary religious experiences of individuals and communities and in the signs of the pneumatic explosions in the lives of transformed individuals who begin to walk and talk like the saved.

The Pentecostal nature of African theology according to Balcomb (2015:9) goes beyond those who are members of Pentecostal churches. Balcomb continues to say that the Spirit becomes an epistemological category within the thinking of African Christians. This implies the belief in a spirit world at the centre of which is Christ and the Holy Spirit (as opposed to ancestors and other spirit beings) which essentially means the agency of the Spirit in all aspects of life, including intentionality and reason. All aspects of life therefore become matters of faith, in the existential, rather than the doctrinally orthodox sense of the word (Balcomb 2015:10).

African Pentecostalism is built on African primal worldview. Gatumu (2000:14) demonstrates how elements and tools derived from the primal worldview can practically aid the apprehension of biblical insinuations. Turner (1977:27) rejects the use of derogatory terms to describe African primal worldview. He promotes the use of the term primal and offers a six-feature analysis on primal religions, which may apportion valid tools to a hermeneutics generated by the primal worldview, and to theology. He also outlines the contribution, which primal religion can make to the study of modem religion. Magesa (1997:24) speaks of moral and ethical values that reside in the African primal worldview and religion, and promote the fullness of life. These define how human beings ought to live. The unity between the natural, the human and the spiritual is an essential ingredient for effecting abundant life. This infuses community life with purpose and harmony.

African Pentecostalism as Hittenberger (2001:221) puts it recognised the need to prepare believers to be effective students of Scripture and articulate ambassadors of Christ. Pentecostals quickly began to establish Bible schools, then Bible institutes, then Bible colleges, then Christian liberal arts colleges and, most recently, theological seminaries. One of the mistakes we can make is to think that a Pentecostal approach has no place in secular universities but only to be taught at Bible colleges and seminaries. Some of the reasons it was limited to secular universities have to do with it being anti-intellectualist. Van Rensburg and Nel (2015:1) say that Pentecostalism allowed for Bible school training with its emphasis on the exclusive study of only the Bible. Butler (2005:347) states that Pentecostals fearful of their children being polluted by the world established Bible schools, normal schools and colleges to promote the Pentecostal message. They set theological boundaries and closed off their conversations with those who dared to believe otherwise. They closed ranks and began to look longingly to the other side of the tracks. 
Nonetheless, African Pentecostalism according to Mckinney (2000:255) is a critical factor because of the tremendous influence it exerts over the trainees and their ministry in the churches or the organisation to which they belong. The purpose of African Pentecostalism as an approach in institution of higher learning is not only to train students to remain faithful to the inspired authoritative word of God, the tenets of faith and the traditional lifestyle and practice, but to equip the students to function in Pentecostal power with the operation of spiritual gifts flowing through them and the congregation.

However, Kärkkäinen (2010:53) argues that while one can easily recognise some core common Pentecostal values and practices reflected in this description, one can hardly take it as a theological outline of what makes Pentecostal theological education distinctive theological. Apart from the more frequent references to the Holy Spirit when compared to typical Evangelical or other Protestant statements, values such as spirituality, biblicism, service, mission and others mentioned here are hardly uniquely Pentecostal commitments.

What Kärkkäinen does not appreciate is that Pentecostalism is not only about the fundamental teachings of Pentecostalism, like baptism in the Holy Spirit with the evidence of speaking in other tongues, but also about divine healing with the use of objects, namely, anointing oil, water, etc. There are new developments in neo-Pentecostalism like prophecy in prophetic churches. In Africa, the gospel is commercialised, whereby congregants are expected to pay some amount to be healed or receive blessings. These new developments need proper analysis and intellectual engagement without which so many pastors and clergy end up doing wrong things. This takes us to the next section on how African Pentecostalism can be incorporated into the theological education in South African universities.

\section{An integration of African Pentecostalism Integration into the curriculum}

The colonial and apartheid curriculum in South Africa has promoted white supremacy and dominance, as well as stereotyping of Africa. The current higher education curriculum still largely reflects the colonial and apartheid worldviews and is disconnected from African realities, including the lived experiences of the majority of black South Africans. Most universities still follow the hegemonic 'Eurocentric epistemic canon' that 'attributes truth only to the Western way of knowledge production' (Heleta 2016:4). Such a curriculum does not develop students' critical and analytical skills to understand and move the African continent forward. The dominant curriculum, according to Naidoo (2016:2), continues to be a source of alienation. The curriculum is also inconsistent with the lived experiences of the majority of African people. Often, the curriculum does not speak to the experiences of students because the curriculum does not reflect the philosophical, social and technological realities of their environment.
One example of an irrelevant theological education curriculum is given by Mbiti as he relates the story of an African theologian who had been trained in Europe, where he attained a doctoral degree in theology. After nine and a half years of study, after getting his junior and senior degrees, he had to return home with the excess baggage which consisted of the Bible in the various languages he had learnt, plus works by Bultmann, Barth, Bonhoeffer, etc. On arriving home, there was a big welcoming occasion of relatives, neighbours, old friends, dancers, musicians and many others. In the midst of the dancing and jubilation, and after he had related his experiences overseas, there was a sudden shriek. It was his older sister who had fallen to the ground. When the wellqualified theologian suggested that she be taken to hospital, he was told that the hospital was far. The theologian was then told that the woman was demon-possessed. When the African theologian tried to refer to Bultmann's explanation in the New Testament, he got a shock that Bultmann had demythologised spirit possession (see Mbiti 1976:8).

Mbiti's example might be a reality among many theological students who receive theological education but cannot apply it to their context. Thus, in our zeal to Africanise the curriculum according to Venter (2016:4), the simple, but profound, questions about whose knowledge and knowledge for whom should be taken very seriously. The nature of epistemic paradigms, of methodologies, of rhetoric or of truth construction and of language comes into play. Theological education curriculum which, in order for it to work effectively for decolonisation through education in specific contexts, according to Mashabela (2017:3), will have to be reconstructed, re-examined, reinterpreted and reconsidered. Buitendag and Simut (2017:3) say that theological education is for everybody: religious or non-religious, clergy or laity, specialists or nonspecialists. Theological education must not only be aimed at everybody but also be performed by everybody.

One of the ways to do this is for African Pentecostalism to be integrated within the current curriculum in the theological education of South African universities. This speaks to issues of recurriculation in the interest of being more relevant to the market or pool of theological students in southern Africa. The reason we need to do this, according to Mckinney (2000:258), is that we cannot teach and model one thing in the theological education of South African universities and expect our products to do something else in the churches where they will minister. As we recognise that we need spiritual renewal and revival in the churches, we must conclude that spiritual renewal and revival are also needed in theological education.

African Pentecostalism should be integrated into the curriculum because it makes the dream of decolonisation and Africanisation of higher education a reality. It makes theological education in South African universities to be engaged with the new developments in southern Africa. In the words of Hadebe (2017:6), generation of knowledge based on African pre-colonial traditions in dialogue with 
contemporary realities is a critical step in dislodging the hegemony of western knowledge and transforming universities into public goods for the benefit of Africa. In order for this to happen, Hadebe suggests that African theologians should continue resisting the hegemony of western theologies by serving the 'market' of the wider social context through theologies developed in dialogue with stakeholders in the commodification process including decolonisation discourses, churches, higher education, government, business, civil society, students, laity and academics.

However, Kay (2004:231) cautions that while African Pentecostalism should be integrated into the curriculum, it should not be associated with narrow Bible school lectures and with an unadventurous pedagogy. The redeeming features of this educational process, however, might lie with the skills of well-experienced scholars who do not necessarily have to be of a Pentecostal background as long as they have a research interest in Pentecostalism, especially in an African context. More relevant to the understanding of this scholastic approach is the placement of Pentecostalism upon the rigorous research. This brings us to the next section of decolonising Pentecostal research.

\section{Decolonising Pentecostal research}

Dreyer (2017:1) opines that the dominant epistemologies, ontologies and methodologies are those that are commonly accepted within the western paradigm of doing research. The academic journals, societies, scholarships and leadership positions are very much dominated by the requirements of the prevailing knowledge system. This calls for what I call decolonisation of Pentecostal research. What I mean by this is that Pentecostal research needs to be conducted in the African context by African scholars.

The following is a non-exhaustive list of the current journals in the subject of Pentecostalism: Asian Journal of Pentecostal Studies, Australasian Pentecostal Studies, Canadian Journal of Pentecostal-Charismatic Christianity, Cyberjournal for Pentecostal-charismatic Research, Encounter: Journal of Pentecostal ministry, International Journal of Pentecostal Missiology, Journal of the European Pentecostal Theological Association, Journal for Pentecostal Theology, The Pentecostal Educator, Pentecostudies, Pneuma, Reflex and Spiritus. Most of these journals, as their names suggest, are very much western. Therefore, there is a need for a Pentecostal Journal of Africa.

Although there are excellent local journals like In Die Skriflig, Acta Theologica, Neotestamatica, Pharos, HTS Theological Studies, Verbum et Ecclessia, Scriptura, Studia Historiae Ecclessiasticae, Stellenbosch Theological Journal, Missionalia and others that normally do not have a problem in publishing research from a Pentecostal perspective, still there is a need for a local journal that will speak for issues of Pentecostalism - something like Journal of Pentecostal Theology in Southern Africa. All I am saying here is that there is a need for a journal that will drive the agenda of African Pentecostalism with an editor who understands such a subject.

\section{A critical research}

Pentecostal theology is based on the experiential that is interpreted in biblical terms, and that its value is determined by its actualisation in daily living. However, African Pentecostal scholars should enhance their distinctive experience-oriented theological education by having scholars who think critically (see Anderson 2004:5). While Pentecostals can and should expect more theological sophistication from their ministers than what these texts provide on their own, Pentecostal theologians would be wise to continue to write academic theology suitable for ministerial training. When doing so, they will need to invite more critical thinking and dialogical thinking with their readers than the 'Bible doctrines' texts do (Stephenson 2009:36). African Pentecostal scholars should not only reflect and emphasise direct communication with God in a way that 'absolve[s] human beings of their responsibility in creating the crisis as well as their role in its resolution'. Uncritical nature of any scholarship leaves research susceptible to mediocre theological reflection that only advances self-interests (see Magezi \& Banda 2017:6).

For many Pentecostals, leaders as well as lay folks, critical activity seems to embody everything that is definitely not Pentecostal at all. Rather, it is perceived to be against the vibrant, dynamic, missionary-oriented practical training so highly valued among Pentecostals. Those fears need to be taken seriously, and one of the tasks of the theological education that embraces Pentecostalism is to reflect on the right balance between critical and constructive work on the one hand and passing on the tradition on the other. Those two tasks are of course neither alternatives nor opposites of each other. Both are needed, yet academia creates pressure to major on one, and the church culture stresses the other, often in a mutually exclusive way (Kärkkäinen 2010:59).

Any university which is set to follow these objectives will have to promote 'critical inquiry, thinking and democratic public engagement'. In other words, a lot of intellectual efforts will have to be invested in training both the members of the academic staff and the students to investigate, research and evaluate everything in a critical way, then in finding meaningful ways to transfer the resulting knowledge into the public life of the local context (Buitendag \& Simut 2017:66). This should be a lesson to the more recent Pentecostal generations to think, and to think critically (Hittenberger 2001:227).

\section{Cutting-edge research}

Dreyer (2017:5) suggests that in response to the call for the decolonisation of knowledge, we have to ask ourselves some critical questions. Are we really engaging with local, African issues in ways that are appropriate to and for Africa, or are we imitating the work of northern hemisphere theologians? What steps do we have to take to decolonise our research practices? How could we work towards epistemic justice in our knowledge-generating activities? 
The answer to Dreyer's first question is that we are not doing enough to engage with the local African issues but are busy copying and pasting a western epistemology. As for the second question, we need to address cutting-edge issues in African Pentecostalism, especially in southern Africa, like the unusual practices of pastors feeding people with snakes, grass, etc. (see Kgatle 2017). Resane has highlighted reasons for unusual practices that include anti-institutionalism, antiintellectualism, anti-nomianism and anti-sacramentalism (see Resane 2016:1). However, one of the reasons such pastors go wrong is that there are no voices that speak their language. They view theology as an outdated western study. There are also societal issues that impact Pentecostalism like poverty, violence, decolonisation, inequality, social cohesion, crime, HIV and aids, corruption, unemployment, health care, land reform, water and sanitation and global warming.

With regard to Dreyer's third question on how could we work towards epistemic justice in our knowledge-generating activities, one cannot provide an easy answer, but one of the ways to do this is for theologians to report back to the communities where they have been conducting their research. In other words, we need to move in two directions as researchers. The first direction is from collection of data to analysing it in a scholarly manner. The second direction is to go back to where we have collected such data and report on our findings. This will make research to be active between communities and the researchers.

The students, according to Haddad (2016:3), also bring to the classroom an interest in a number of wide-ranging sociopolitical, economic and environmental concerns, including areas of my particular expertise, gender and development and the response of the faith community to HIV in sub-Saharan Africa. Buitendag and Simut (2017:7) say that each context has 'local knowledge and objectives', and these must be considered important for the betterment of the life of the people in the region, although the kind of education and research produced by the local university should be 'cutting edge with a global reach'. This clearly presupposes the existence of a 'larger vision' which is shared not only by the top management university team but also by the academic staff and the students (Buitendag \& Simut 2017:7). In other words, what Buidendag and Simut are suggesting here is that although research in African Pentecostalism is cooked in an African pot, there is a need to dish it out to the international community.

\section{Integrated theological education}

The University, where I am currently serving as senior lecturer, comprises researchers who come from Reformed, Lutheran, Baptist, Catholic and even Pentecostal backgrounds. Hence, examples of theological institutions seeking to Africanise their theology would, according to Naidoo (2016:2), be the University, which is 'proudly African in the service of humanity'. This wording, Naidoo (2016) continues to say, refers to an attempt to be: relevant in the communities in which they are serving and working by trying to ensure that they are relevant to the African context by ensuring that the lens through which they approach the design of curricula is an African lens. (p. 2)

In theological education, especially at a public university according to Anderson (2004:2), we should not be in a process of being faithful to the particular doctrines of a specific church. Equally so, we should not attempt to please everyone but engage one another. Anderson suggests that theological education in the 21st century needed to have the diverse voices from different approaches that make up scholarship and must be 'encouraged and expected to speak their own theological language' in order to strengthen and critique the community of scholars (Anderson 2004:2).

In order to listen and hear such diverse voices according to Kay (2004), there should be:

Encouragement of student-faculty contact; encouragement of cooperation among students; active learning; prompt feedback; emphasis on time on task; high expectations; and respect for diverse talents and ways of learning. Values and goals should be used as criteria for evaluating and developing a curriculum. These values would be developed from biblical perspectives including those that allow for the expression of prophetic and healing models of excellence. There should be a holistic approach that insisted upon 'intentional interaction between theory and practice' so that there was no division between the superstructure of Christian doctrine and the infrastructure of Christian practice. (p. 234)

Theological education in that kind of mixed environment of expectations would be greatly and invaluably served by a committed and academically as well as spiritually alert theological guild that would ask the kinds of critical questions seldom asked by the scholars (Kärkkäinen 2010:58). This entails, among other things, an orientation of utmost respect for the other as a human being, respect for the other's culture, language, traditions, religion, spirituality and so forth. The immense difficulty of doing theological research in a context with so much diversity is obvious. It requires knowledge of these cultural and other practices and a well-developed sensitivity and personal maturity. The research situation is rife with opportunities that could lead to misunderstanding, the strengthening of stereotypes and the prolongation of inequality. These pitfalls are intrinsic to all research practices but gain particular prominence in research in postcolonial contexts (Dreyer 2017:6).

In the university and beyond it, theology must watch over all kinds of faiths in order to educate as many people as possible regarding 'inadequate public understanding of faith' which many call 'foolish', 'dangerous' and 'ignorant'. In higher education, theology must seek to improve human life in all its forms virtually everywhere in the world by providing people with trustworthy comprehension of belief(s) (Buitendag \& Simut 2017:2). In South Africa, the task of creating a curriculum that is fit for the post-1994 era is to open the space for 'diverse ontological narratives' (Naidoo 2016:4). 


\section{Contextual theological education}

There is a need for a contextual theological education because according to Balcomb (2015):

theological education in the secular academy can alienate its graduates from their faith, their context, and their people. This should cause us to be concerned about why this is the case. The main reasons for such alienation are to do with influences of the Enlightenment on the secular academy due to the particular intellectual history of the West. African theology has a different history that continues to unfold a different set of interests, values, priorities, and ways of being and thinking. While Western history cannot be wished away it should not be allowed to dictate this African unfolding. At the least an African perspective needs to be a major dialogue partner in the theological enterprise in the South African academy. At most it should be allowed to write an agenda upon which the conversation takes place. Otherwise we will continue to have the untenable situation where the two histories, while profoundly impacting on each other in society, will not be allowed to dialogue with each other in the academy. (p. 11)

Theological colleges in South Africa and in many other places in the world were answering questions that no one was asking, and worse, not answering questions that most people were asking. The context of theological education is not the Bible college, the seminary or the university but the community in which God's people are found. Only when the context is clear in our minds can we begin to adjust the content of our education, and this is true for South Africa as for anywhere else (Anderson 2004:3). In other words, a fixed body of knowledge should not be imposed upon students within various cultural settings. Rather, the cultural setting should help to inform each programme of tuition. As a result, theological education ought to vary from culture to culture and will adapt itself to local needs and situations (Kay 2004:233).

In order to attract more students in theological education, there is a need for a theological education that is relevant to the needs of the students, especially in the African context. It is believed here that by incorporating African Pentecostalism in theological education, more students will be attracted to the faculty or school of theology. However, faculties need to do more than incorporating Pentecostalism in theological education. The whole curriculum needs to address the real needs of the students and the churches they will be ministering in. According to Venter (2016:2), at the heart of the struggle of theology to come to terms with the challenge of transformation is the need for a new contextual theology, one that adequately responds to the post-apartheid context in its multifaceted character.

According to Mckinney (2000:259), the reason why sometimes theological education is irrelevant is because often leaders and teachers in institutions have arrived at their philosophy of ministry from biblical understanding and educational experience without having had extended ministry in a church setting. This could be a contributing factor to differing philosophies of the role of theological education in preparing pastors and church leaders for effective ministry in their churches. The need for African Pentecostalism in theological education by all who lead and teach in universities is a crucial factor in shaping the lives and ministries of their products (Mckinney 2000:259).

\section{Kärkkäinen (2010) says that:}

An academic institution of theological knowledge 'exists as a place where definite, charismatic, revelational knowledge and certainty exist alongside and in interaction with the indefinite but progressive search for truth', whereas a typical church setting calls for a definite authoritative settling of the issues under discussion. In order to keep this dynamic tension in a healthy measure, leaders and pastors will have to acknowledge that their revelational knowledge and ecclesial authority is not absolute, while teachers will have to admit that their academic freedom and scholarly knowledge are not absolute goods. (p. 57)

In order for Africa to rectify the damages of its colonial past and also have a chance at long-lasting results, any programme of decolonisation must be approached contextually in keeping with local needs and problems. For this to happen, however, decolonisation must become a reality that is constantly fuelled intellectually and then unceasingly fostered practically in such a way that continuity, durability and permanence turn into its most valued assets (Buitendag \& Simut 2017:1). Therefore, generally speaking, education means identifying with the poorest of the poor, making a preferential option for the poor and being there to solve Africa's sociocultural problems (Methula 2017:5). Theological education must be delinked from the imperial/modern claims of universality that continue epistemic colonisation and the global matrix of power towards relinking with African thought patterns rooted and grounded in Ubuntu, communalism and care for the environment (Methula 2017:6).

Therefore, we need to provide contextualised and diversified theological education that allows for greater 'access to theological education in order to equip all God's people to be able to meet the contextual needs and development of their immediate social and ecumenical context'. The capacity to respond to social context is critical for ministers and priests today. There is a 'growing need for ministers to interpret the socio-economic, cultural, political and spiritual context of the majority with the aim of transforming these contexts' (Hadebe 2017:3). Theological education is, therefore, challenged to instil a sound, liberating and empowering theology of work to enable the poor to be productive citizens. This calls for theological education that unlocks a sound theology of work. On the characteristics of being created in the image of God is the ability to be creative, which means that work is not only for survival's sake but also an expression of being in the image of God (Magezi \& Banda 2017:5).

\section{Conclusion}

This article has demonstrated an urgent need and demand for a theological education that will be relevant to Africa. It suggests an approach that will incorporate African 
Pentecostalism into the theological education of South African universities. However, the article cautions that African Pentecostalism should not be prescribed as a dominating approach but rather as part of an integrated theological education. Hence, a suggestion to incorporate African Pentecostalism in the curriculum, decolonisation of Pentecostal research and emergence of critical African scholars that can address cutting-edge issues in a South African context. In doing so, a theological education in South African universities shall be a contextual and relevant one.

\section{References}

Alvarez, M., 2000, 'Distinctives of Pentecostal education', Asian Journal Pentecostal Studies 3, 282-293.

Amanze, J.N., 2012, 'The voicelessness of theology and religious studies in contemporary Africa: Who is to blame and what has to be done? Setting a new agenda', Missionalia 40(3), 189-204.

Anderson, A., 2004, 'Pentecostal-charismatic spirituality and theological education in Europe from a global perspective', PentecoStudies 3(1), 1-15.

Balcomb, A.O., 2015, 'Theological education in South Africa and the epistemological divide: In search of the African habitus', Scriptura 114, 1-12. https://doi.org/ $10.7833 / 114-0-1039$

Buitendag, J. \& Simut, C.C., 2017, 'Teaching theology at African public universities as decolonisation through education and contextualisation', HTS Teologiese Studies/ Theological Studies 73(1), a4806. https://doi.org/10.4102/hts.v73i1.4806

Butler, A., 2005, 'Pentecostal traditions we should pass on: The good, the bad and the ugly', Pneuma 27(2), 343-353. https://doi.org/10.1163/157007405774857391

Dreyer, J.S., 2017, 'Practical theology and the call for the decolonisation of higher education in South Africa: Reflections and proposals', HTS Teologiese Studies/ Theological Studies 73(4), a 4805. https://doi.org/10.4102/hts.v73i4.4805

Gatumu, A.K.W., 2000, 'Primal worldview and the Bible: An African Christian contribution to a hermeneutical method from the perspective of the primal worldview, with particular reference to the Gikuyu of Kenya', Doctoral dissertation, Worldview, with partic
University of Natal.

Haddad, B., 2016, 'Curriculum design in theology and development: Human agency and the prophetic role of the church', HTS Teologiese Studies/Theological Studies 72(4), a3432. https://doi.org/10.4102/hts.v72i4.3432

Hadebe, N.M., 2017, 'Commodification, decolonisation and theological education in Africa: Renewed challenges for African theologians', HTS Teologiese Studies/ Theological Studies 73(3), a4550. https://doi.org/10.4102/hts.v73i3.4550

Heleta, S., 2016, 'Decolonisation of higher education: Dismantling epistemic violence and Eurocentrism in South Africa', Transformation in Higher Education 1(1), 1-8. https://doi.org/10.4102/the.v1i1.9

Hittenberger, J.S., 2001, 'Toward a Pentecostal philosophy of education', Pneuma 23(1), 217-244. https://doi.org/10.1163/157007401X00186

Hollenweger, W.J., 1986, 'After twenty years' research on Pentecostalism', International Review of Missions 75(297), 3-12. https://doi.org/10.1111/j.1758 6631.1986.tb01446.x

Kalu, O., 2008, African Pentecostalism: An introduction, Oxford University Press, Oxford.
Kärkkäinen, V.M., 2010, 'Pentecostal theological education in a theological and missiological perspective', Journal of the European Pentecostal Theological Association 30(1), 49-62. https://doi.org/10.1179/jep.2010.30.1.005

Kay, W.K., 2004, 'Pentecostal education', Journal of Beliefs \& Values 25(2), 229-239. https://doi.org/10.1080/1361767042000251636

Kgatle, M.S., 2017, 'The unusual practices within some Neo-Pentecostal churches in South Africa: Reflections and recommendations', HTS Teologiese Studies/ Theological Studies 73(3), a4656. https://doi.org/10.4102/hts.v73i3.4656

Letsekha, T., 2013, 'Revisiting the debate on the Africanisation of higher education: An appeal for a conceptual shift', The Independent Journal of Teaching and Learning 8(1), 5-18.

Magesa, L., 1997, 'From a privatized to popular hermeneutics in Africa', in H. Kinoti \& J. Waliggo (eds.), The Bible in African Christianity, pp. 25-39, Action Press, Nairobi.

Magezi, V. \& Banda, C., 2017, 'Christian ministry and theological education as instruments for economic survival in Africa', HTS Teologiese Studies/Theological Studies 73(3), 4545. https://doi.org/10.4102/hts.v73i3.4545

Mashabela, J.K., 2017, 'Africanisation as an agent of theological education in Africa', HTS Teologiese Studies/Theological Studies 73(3), a4581. https://doi.org/10.4102/ hts.v73i3.4581

Mashau, T.D., 2003, 'Africanisation of Christianity and theology: A Reformational perspective', Journal of Theology and Religion in Africa 27(1), 123-143.

Mbiti, J.S., 1976, 'Theological impotence and the universality of the Church', in G.H. Anderson \& T.F. Stransky (eds.), Mission trends no. 3, pp. 6-18, Paulist Press, New York.

McKinney, E.L., 2000, 'Some spiritual aspects of Pentecostal education: A personal journey', Asian Journal of Pentecostal Studies 3(2), 253-279.

Methula, D.W., 2017, 'Decolonising the commercialisation and commodification of the university and theological education in South Africa', HTS Teologiese Studies/ Theological Studies 73(3), a4585. https://doi.org/10.4102/hts.v73i3.4585

Naidoo, M., 2016, 'Overcoming alienation in Africanising theological education', HTS Teologiese Studies/Theological Studies 72(1), Art. \#3062, 8 pages. https://doi. org/10.4102/hts.v72i1.3062

Pewforum, 2011, Global Christianity - A report on the size and distribution of the World's Christian population, viewed 19 December 2011, www.pewforum.org.

Ramantswana, H., 2016, “I shavha i sia muinga i ya fhi?": Decolonial reflection on African biblical hermeneutics', Stellenbosch Theological Journal 2(2), 401-429.

Ramantswana, H., 2017, 'Beware of the (Westernised) African eyes: Rereading Psalm 82 through the vhufa approach', Scriptura 116, 1-18.

Resane, K.T., 2016, "And they shall make you eat grass like oxen" (Daniel 4:24): Reflections on recent practices in some New Charismatic Churches', Pharos Journal of Theology 98, 1-17.

Stephenson, C.A., 2009, 'Pentecostal theology according to the theologians: An introduction to the theological methods of Pentecostal systematic theologians', DPhil Dissertation, Graduate School, Marquette University.

Turner, H., 1977, 'Primal religions and their study', in V. Hayes (ed.), Australian essay in world religion, pp. 27-37,Australian Study of Religion, Bedford Park.

Van Rensburg, F. \& Nel, M., 2015, 'The long and arduous journey of theological training in the AFM of SA'. In die Skriflig 50(2), 1-10.

Venter, R., 2016, 'Theology and the (post-) apartheid university: Mapping discourses, interrogating transformation', Transformation in Higher Education 1(1), a5. https://doi.org/10.4102/the.v1i1.5

Wahl, W.P., 2013, 'Towards relevant theological education in Africa: Comparing the international discourse with contextual challenges', Acta Theologica 33(1), 266-293. https://doi.org/10.4314/actat.v33i1.14

Yong, A., 2007, 'Pentecostals and the theological academy', Theology Today 64(2), 244-250. https://doi.org/10.1177/004057360706400209 